\title{
A facile synthesis of trans-alkenes in micellar media
}

\author{
Xiang-Min Wen, Lan Tao, Yong-Zhe Xiang, Yu-Guo Fang, and Xiao-Qi Yu* \\ Department of Chemistry, Key Laboratory of Green Chemistry and Technology \\ (Ministry of Education), Sichuan University, Chengdu, Sichuan 610064, P. R. China \\ E-mail:schemorg@mail.sc.cninfo.net
}

(received 01 Feb 05; accepted 02 May 05; published on the web 07 May 05)

\begin{abstract}
In this paper, trans-alkenes were selectively synthesized in micellar media in high yields under very mild and effective reaction conditions. The cationic as well as the crown ether micellar systems have similar catalytic effect on the olefination, and the catalytic systems formed by the cationic and crown ether surfactants are far-forth superior to the anionic micellar system.
\end{abstract}

Keywords: Trans-Alkenes, synthesis, micelles, olefination

\section{Introduction}

Reactions in micellar solutions have received a great deal of interest in the last decades. ${ }^{1-2}$ Micelles, just like enzymes, form microdomains in water. These microdomains may bind apolar molecules and may promote the conversion of these molecules into products. As a simple model of enzyme, micelle can catalyze many complex organic reactions. A number of micellar reactions were reported to mimic the biochemical process, such as hydrolysis of esters ${ }^{3}$ and oxidation of alkenes or alkanes. ${ }^{4}$ However, the examples of investigations of carbanionic reactions in micellar system are rare. Several reports were focused on an experimental procedure for the preparation of olefins employing strong bases (sodium hydride, butyllithium) under anhydrous conditions. ${ }^{5}$ The phase-transfer methods were also effectively used for the generation of alkenes via Wittig-Horner reaction. These works have demonstrated that the reaction in a twophase system catalyzed by quaternary ammonium salts and crown ethers affords a mixture of $(E)$ - and (Z)-isomers. ${ }^{6-9}$ The present paper reports a highly selective synthesis of trans-alkenes via the Wittig-Horner reaction in a micellar solution formed by various surfactants, such as Brij 35 and lauryl trimethylammonium bromide. By using this reaction system (Scheme 1), we can conveniently obtain the trans-alkenes in high yields. 


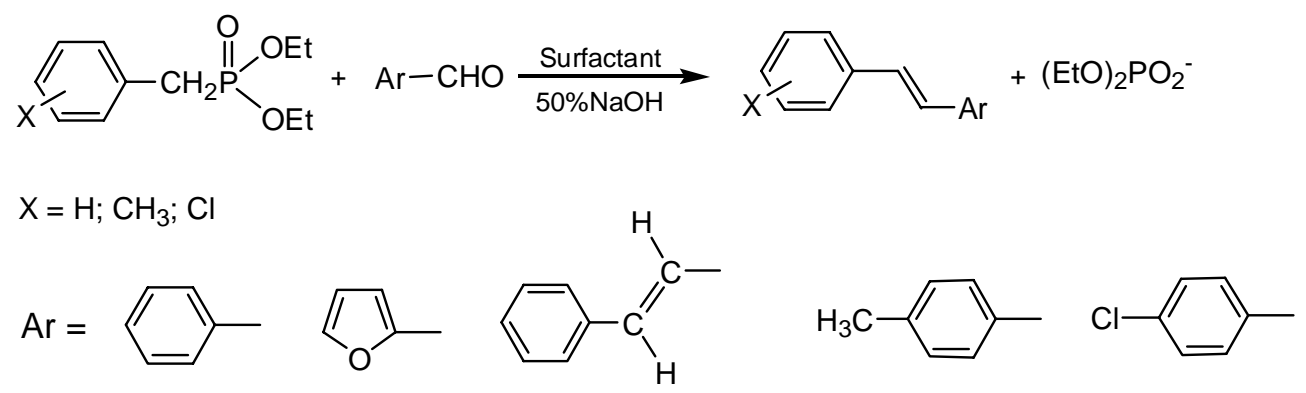

Scheme 1. The description of Wittig-Horner reaction.

\section{Results and Discussion}

As well known, Wittig-Horner reaction can be used for the preparation of alkenes in good yield and with trans-selectivity only in the presence of strong bases, such as sodium alkoxides and sodium hydride. ${ }^{5,6,13-15}$ We have found that trans-alkenes can be obtained in good yields in the presence of $50 \%$ aqueous sodium hydroxide by addition of surfactant to form micellar system. This is a mild, effective synthetic method for the selective preparation of trans-alkenes.

As outlined in Table 1, the yields of trans-alkenes are in relation to the structures of aromatic aldehydes. Almost all of the aromatic aldehydes afforded trans-alkenes in excellent yields (up to $99 \%$, entries 1, 3, 4 and 6-9) except $p$-chlorobenzaldehyde, which reacted with diethyl benzyl phosphonate to produce the corresponding trans-alkene in a relatively low yield (82\%, entry 5). According to general micellar structure described in literature, the surfactant hydrophobic group forms the core of micelle, and the reaction takes place in the Stern layer of micellar structures. The quaternary ammonium head-groups of the surfactant molecules can form ion pairs with the hydroxide ions. The result enables hydroxide ions to aggregate at the interface of micellar structures and enhances the formation of carbanion. This also facilitates the attack of carbanion on the CO moiety. 
Table 1. Synthesis of trans-alkenes in lauryl trimethylammonium bromide micellar media ${ }^{\mathrm{a}}$

Entry

${ }^{\mathrm{a}}$ Reaction time: $24 \mathrm{~h}$; reaction temperature: $25^{\circ} \mathrm{C} .{ }^{\mathrm{b}}$ All yields reported in this table are those of the crystallized pure products. ${ }^{c}$ Values in parentheses are from literature ${ }^{6,14}$. ${ }^{\mathrm{d}} \mathrm{Z} / \mathrm{E}$ ratio was determinated by ${ }^{1} \mathrm{HNMR}$ spectra of trans-, cis-H located at carbon-carbon double bond. ${ }^{\mathrm{e}}$ The product is E-E isomer.

From Table 2 we can see that the micellar structures have significant effect on the olefin yields, and the results demonstrate that the catalytic effect of micelles formed by cationic surfactants (entries 3, 4 and 5, alkene yields are up to 99\%) is superior to anionic micelle (entry 9 , alkene yield is only 22\%). That is to say, cationic micelles catalyze the olefination between phosphonate and substituted aldehydes, and anionic micelles retard this reaction. This is because the anionic micelle cannot form ion pairs with hydroxide ions at the interface of micelles and therefore the formation of carbanionic intermediates in the reaction media is not easy. Ion-pair formation also explains the effect of the surfactant head-group size on the hydroxide ion promoted olefination. The tendency of the quaternary ammonium head-groups to form ion pairs 
with $\mathrm{OH}^{-}$ions will decrease when the size of the head-group increase. This results in a reduction in $\mathrm{OH}^{-}$concentration in the micellar pseudophase where the substrates reside. The reduction in $\mathrm{OH}^{-}$concentration would lead to the lower product yields (entries 3 and 5). We have observed the same catalytic effect on Wittig-Horner reaction catalyzed by the micelles formed by a crown ether-like surfactant, which was synthesized according to our previous method ${ }^{11}$ (entry 2). This result confirms that the crown ether micelle has better effect on the olefination than open chain polyethylene glycols. Because the micellar structure formed by crown ether surfactant can coordinate with sodium ion at the interface of micelle, the result is similar to the microenvironment formed by the cationic micelle. So the olefin yield is similar to that catalyzed by the cationic micellar systems. When nonionic micelles were chosen as the reaction media for the olefination, the results indicated that the nonionic micelles have moderate activities on the olefination (entries 6, 7 and 8 in Table 2). All above-mentioned micellar catalytic systems produced excellent trans-olefination selectivities (up to $99 \%$ ).

Table 2. Effect of different miceller media on Wittig-Horner reaction

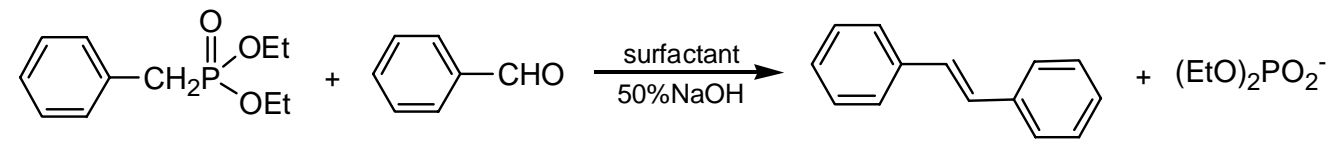

\begin{tabular}{|c|c|c|c|}
\hline Entry & Surfactant & $\begin{array}{l}\text { Yield of (E)- } \\
\text { isomer (\%) }\end{array}$ & $\begin{array}{l}(Z):(E) \\
\text { ratio }^{\text {b }}\end{array}$ \\
\hline 1 & -- & 14 & $<1 / 99$ \\
\hline 2 & Decyloxymethyl-15-C-5 & 97 & $<1 / 99$ \\
\hline 3 & Lauryl trimethylammonium bromide & 99 & $<1 / 99$ \\
\hline 4 & Decyl trimethylammonium bromide & 98 & $<1 / 99$ \\
\hline 5 & Lauryl benzyldimethylammonium chloride & 93 & $<1 / 99$ \\
\hline 6 & Polyglycol octylphenylate & 69 & $4 / 96$ \\
\hline 7 & Brij 35 & 67 & $<1 / 99$ \\
\hline 8 & Brij 58 & 63 & $<1 / 99$ \\
\hline 9 & Sodium dodecyl sulfonate & 22 & $<1 / 99$ \\
\hline
\end{tabular}

${ }^{\mathrm{a}}$ All yields reported in this table are those of the crystallized pure products. ${ }^{\mathrm{b}} \mathrm{Z} / \mathrm{E}$ ratio was determinated by ${ }^{1} \mathrm{HNMR}$ spectra of trans-, cis-H located at carbon-carbon double bond $\left(\delta_{c i s}=\right.$ $\left.6.60 \mathrm{ppm}, \delta_{\text {trans }}=7.11 \mathrm{ppm}\right)$.

In conclusion, trans-alkenes were selectively synthesized in micellar media in high yields under very mild and effective reaction conditions. Cationic as well as crown ether micellar systems have the similar catalytic effect on the olefination. With these systems we can obtain 
alkenes in high yields and with high trans-selectivities. The catalytic systems formed by cationic and crown ether surfactants are far-forth superior to the anionic micelles.

\section{Experimental Section}

General Procedures. ESI-MS spectra data were recorded on Finnigan CCQ $^{\text {DECA }}$ mass spectrometer. ${ }^{1} \mathrm{H}$ NMR spectra were measured on a Varian INOVA-400 spectrometer and chemical shifts in ppm are reported relative to internal $\mathrm{Me}_{4} \mathrm{Si}\left(\mathrm{CDCl}_{3}\right)$. Elemental analyses were performed by using a Carlo-Erba 1106 elemental analytical instrument. Melting points were determined by using a micro-melting point apparatus without any corrections. All surfactants and reagents were obtained commercially and used without further purification. Diethyl substituted benzyl phosphonates were synthesized according to previous report. ${ }^{10}$ Decyloxy methyl-15crown-5 was synthesized by previous method ${ }^{11}$. The CMC of decyloxy methyl-15-crown-5 was determined by Du Nouy interface Tensiomter (CMC $=35.0 \times 10^{-2} \mathrm{mg} / \mathrm{mL}$ ). The CMCs of lauryl trimethylammonium bromide, polyglycol octyl phenylate, Brig 35, Brij58 and sodium dodecyl sulfonate were obtained from literature. ${ }^{12}$

\section{General procedure for the synthesis of trans-alkenes via Wittig-Horner reaction in micellar media}

Surfactant was added to a $80 \mathrm{~mL}$ aqueous sodium hydroxide (50\%) (the concentration of surfactant is 10 -fold mol of CMC), and the mixture was stirred about $15 \mathrm{~min}$ at $25{ }^{\circ} \mathrm{C}$, then 4 mmol diethyl substituted benzyl phosphonate and $4 \mathrm{mmol}$ aldehyde were added. After the mixture was stirred about $24 \mathrm{~h}$ at $25^{\circ} \mathrm{C}, 50 \mathrm{~mL}$ water and $25 \mathrm{~mL}$ ether were added. The solution was extracted four times by ether, and ether layer were combined and dried by anhydrous $\mathrm{MgSO}_{4}$. Solvent was removed under reduced pressure to give a white solid. The selectivity was determined by the ${ }^{1} \mathrm{H}$ NMR spectra of reaction mixture. The products were recrystallized from ethanol to form pure trans-alkenes as lamellar crystals, and the resulting substituted 1,2diphenylethylenes were identified by melting point, ${ }^{1} \mathrm{H}$ NMR and elemental analysis.

\section{Acknowledgements}

This work was financially supported by the National Natural Science Foundation of China (20132020, 20372051), Program for New Century Excellent Talents in University, Specialized Research Fund for the Doctoral Program of Higher Education and Scientific Fund of Sichuan Province for Outstanding Young Scientist. 


\section{References and Footnotes}

1. Cleij, M. C.; Nolte, R. J. M. J. Org. Chem. 1991, 56, 3883.

2. (a) Jursic, B. Tetrahedron 1988, 44, 6677. (b) Zingaretti, L.; Boscatto, L.; Chiacchiera, S. M.; Silber, J. J. ARKIVOC 2003, (x), 189.

3. (a) Cleij, M. C.; Drenth, W.; Nolte, R. J. M. Recl. Trav. Chim. Pays-Bas 1992, 111, 459. (b) Zakharova, L. Y.; Valeeva, F. G.; Kudryavtseva, L. A.; Konovalov, A. I.; Zakharchenko, N. L.; Zuev, Y. F.; Fedotov, V. D. Russ. Chem. Bull. 1999, 48, 2240. (c) Tonellato, U. Pure Appl. Chem. 1998, 70, 1961. (d) Jiang, F.-B.; Jiang, B.-Y.; Cao, Y.-S.; Meng, X.-G.; Yu, X.Q.; Zeng, X.-C. Colloids Surf. A: Physicochem. Eng. Aspects 2005, 254, 91. (e) Jiang, F.-B.; Du J.; Yu, X.-Q.; Bao, J.-K.; Zeng, X.-C. J. Colloid Interface Sci. 2004, 273, 497. (f) Jiang, F.-B.; Jiang, B.-Y.; Chen, Y.; Yu, X.-Q.; Zeng, X.-C. J. Mol. Catal. A: Chem. 2004, $210,9$. (g) You, J.-S.; Yu, X.-Q.; Su, X.-Y.; Wang, T.; Xiang, Q.-X.; Yang, M.; Xie, R.-G. J. Mol. Catal. A, Chem. 2003, 202, 17. (h) Xiang, Q.-X.; Yu, X.-Q.; Su, X.-Y.; Yan, Q.-S.; Wang, T.; You, J.-S.; Xie, R.-G. J. Mol. Catal. A, Chem. 2002, 187, 195. (i) Xiang,Q.-X.; Yu, X.Q.; You, J.-S.; Yan, Q.-S.; Xie, R.-G. Chin. J. Chem. 2001, 19, 158. (j) You, J.-S.; Yu, X.Q.; Liu, K.; Tao, L.; Xiang, Q.-X.; Xie, R.-G. Tetrahedron: Asymmetry 1999, 10, 243. (k) You, J.-S.; Yu, X.-Q.; Li, X.-S.; Yan, Q.-S.; Xie, R.-G. Tetrahedron: Asymmetry 1998, 9, 1197.

4. (a) Lan, Z.-W.; Yu, X.-Q.; Chen, J.-T.; You, J.-S.; Zhao, H.-M. Chin. J. Org. Chem. 1995, 15, 47. (b) Heijnen, J. H. M.; de Bruijn, V. G.; van den Broeke, L. J. P.; Keurentjes, J. T. F. Chem. Eng. Proc. 2003, 42, 223. (c) van den Broeke, L. J. P.; de Bruijn, V. G.; Heijnen, J. H. M.; Keurentjes, J. T. F. Ind. Eng. Chem. Res. 2001, 40, 5240. (d) Panicheva, L. P.; Turnaeva, E. A.; Panichev, S. A.; Yuffa, A. Y. Petro. Chem. 2001, 41, 32.

5. (a) Dopp, D. ARKIVOC 2000, (vi), 939. (b) Boutagy, J.; Thomas, R. Chem. Rev. 1974, 74, 87.

6. Piechucki, C. Synthesis 1974, 869.

7. Mikolajczyk, M.; Grzejszczak, S.; Midura, W.; Zatorski, A. Synthesis 1975, 278.

8. Piechucki, C. Synthesis 1976, 187.

9. Mikolajczyk, M.; Grzejszczak, S.; Midura, W.; Zatorski, A. Synthesis 1976, 396.

10. Li, Z.-K.; He, C.; Yang, M.; Xia, C.-Q.; Yu, X.-Q. ARKIVOC 2005, (i), 98.

11. Yu, X.-Q.; Lan, Z.-W.; Zhao, H.-M. Chin. J. Org. Chem. 1994, 14, 176.

12. Shinoda, K.; Nakagawa, T.; Tamamushi, B.-I.; Isemura, T. In Colloidal Surfactants; Academic Press: New York, 1963.

13. Breuer, E.; Bannet, D. M. Tetrahedron 1978, 34, 997.

14. Tewari, R. S.; Kumari, N.; Kendurkar, P. S. J. Chem. Eng. Data 1976, 21, 125.

15. Breuer, E.; Bannet, D. M. Tetrahedron 1977, 33, 1141. 